Educational Research for Social Change (ERSC)

Volume: 5 No. 2, September 2016

pp. 35-51

ersc.nmmu.ac.za

ISSN: 2221-4070

\title{
Vulnerability and Children's Real-Life Schooling Experiences in Swaziland
}

Ncamsile Daphne Motsa

Pholoho Justice Morojele

University of KwaZulu Natal, South Africa

Morojele@ukzn.ac.za

\section{Abstract}

This paper foregrounds vulnerable children as a social group whose experiences should be studied and understood from their own perspectives. The paper explores the real-life schooling experiences of six Grade 6 vulnerable children, aged between 11-15 years, in a rural primary school in the Lubombo region of Swaziland. Guided by a theoretical paradigm of social constructionism, the paper engages dynamics of children's vulnerability within this context, ravaged by poverty and HIV and AIDS. The aim is to contribute insights to our understanding on how we might improve vulnerable children's quality of schooling and educational experiences. A qualitative narrative approach was adopted, using semi-structured individual and focus group interviews and a participatory research method, photovoice, for data generation. The findings indicate that vulnerable children carried trauma caused by life experiences that affected their learning. They were also found to be lacking necessities like candles to help them with studying, and had additional family responsibilities that competed with their study time. Teachers' administration of corporal punishment was found to be inequitably skewed against vulnerable children, thereby exacerbating their schooling plight.

Keywords: vulnerability, children, schooling, experiences, rural, Swaziland

Copyright: (C) 2016 Motsa \& Morojele

This is an open access article distributed under the terms of the Creative Commons Attribution Non-Commercial License, which permits unrestricted non-commercial use, distribution, and reproduction in any medium, provided the original author and source are credited.

Please reference as:

Motsa, N. D. \& Morojele, P. J. (2016). Vulnerability and Children's Real-Life Schooling Experiences in Swaziland. Educational Research for Social Change, 5(2), 35-51. http://dx.doi.org/10.17159/22214070/2016/v5i2a3 


\section{Introduction}

In the year 2016, alone, Swaziland had about 150,000 vulnerable children in the country's schools-a drastic increase from 78,000 in 2015 (Simelane, 2016). The Kingdom of Swaziland (2010) defines a vulnerable child as one, with or without parents, who lacks the basic needs for survival, and is living in circumstances with high risk, and whose prospects for health, growth, and development are seriously impaired, mostly due to the effects of HIV and AIDS. Within the Swaziland education system, vulnerable children are considered to include orphans, children living in child-headed households, and those from poor social and economic backgrounds. Vulnerable children are locally referred to as bantfwana bendlunkhulu [those cared for by the whole community] and whose educational fees are paid by the government. Although the reasons that render children vulnerable may differ, for instance, orphaned children, those experiencing childhood poverty, and children living in child-headed households in Swaziland, these children share one thing-and that is vulnerability and poverty (Nordtveit, 2010). It is against this backdrop that the study adopted the concept of vulnerable children in order to understand the shared real-life schooling experiences of these children. Although the article is about vulnerable children's experiences within school (or learning) spaces, we avoided referring to them as vulnerable learners so as to emphasise the social (rather than the didactical) dimensions of the vulnerable children's real-life schooling experiences.

In 1990, Swaziland committed itself to the Eight Millennium Development Goals (MDG) aimed at focusing on poverty and the needs of all children by 2015 (Khumalo, 2013). The country also became a signatory to the Dakar Framework for Action: Education for All, which formed the basis for inclusive educational policies in the country (Kingdom of Swaziland, 2011). By signing these declarations, the state devoted itself to improving education, especially for the most vulnerable and underprivileged children in the country (UNESCO, 2000). Guided by these conventions, in 2003, the government of Swaziland introduced the Orphaned and Vulnerable Children's (OVC) fund to cater for vulnerable children's educational fees (Kingdom of Swaziland, 2012). The country's constitution of 2005 also offered a legal framework for the rights of all children and set an objective of free primary education (Kingdom of Swaziland, 2005). In 2011, the Ministry of Education and Training consequently designed the Education Sector Policy, which was underpinned by international, regional, and national declarations on the rights of all children. This policy outlines the state's goals towards the improvement of vulnerable children's lives by identifying, monitoring, and accommodating their educational needs (Kingdom of Swaziland, 2011).

Even after adopting the aforementioned conventions, laws, and policies, Swaziland has not fully succeeded in implementing them at a practical level (Sukati, 2013). For example, Nordtveit (2010) found that school practices, and teachers in Swaziland, still exclude vulnerable children; and these children were also found to have a predisposition for exploitation and sexual abuse by some teachers (Swaziland Action Group Against Abuse, 2013), which forces them to drop out of school (Nordtveit, 2010) at a higher rate than children who are not regarded as vulnerable. Such a scenario increases vulnerable children's risk of being trapped in a vicious cycle of poverty and vulnerability because it deprives them of their right to education, which is a prerequisite for a better and gracious later life. It actually contravenes vulnerable children's right to basic learning needs of fair and dignified treatment, which is necessary for them to complete quality school education (UNESCO, 2000) as ratified by the Dakar Framework for Action, to which Swaziland subscribes. Clearly, more needs to be done, therefore, to comprehend the daily life experiences of vulnerable children in light of these possible policy-practice discrepancies. Hence, we undertook this study, which tries to shed insights on the reallife schooling experiences of vulnerable children in this context. To address this policy-practice gap, the paper combines narrative interviews with photovoice imagery to bring to the research world a glimpse of the vulnerable children's voices as they expressed their feelings and opinions related to their schooling experiences. In this rural context, education is seen as the only hope for breaking the 
circle of poverty and vulnerability (Sutton, Smith, Dearden, \& Middleton, 2007), hence the need to open debates and conceptualisations of new possibilities for educational reforms aimed at enhancing the schooling opportunities of vulnerable children.

\title{
Social Constructionism as Theoretical Perspective
}

One inevitable question that must be answered is, "What is it about social constructionism that makes it appropriate as a theoretical perspective for studying real-life schooling experiences of vulnerable children in school contexts?" At the heart of social constructionism is the view that vulnerable children's ways of constructing their real-life schooling experiences are generated by relations, rather than by external realities (Gergen, 2009). Social constructionism's emphasis is on discourse and social relations as bases on which vulnerable children's real-life schooling experiences are predicated. Gee (2011) saw discourse as a socially accepted association among ways of thinking, feeling, believing, valuing, and of acting that can be used to identify oneself as a member of a socially meaningful group. McCann \& Kim (2003) posited that a discourse is not a language or a text, but a historically, socially, and institutionally specific structure of statements, terms, categories, and beliefs. Therefore, discursively constituted social relations are key phenomena informing vulnerable children's views about the world, and their relationships with wider society, family, and the school, and vice versa (Gergen \& Gergen, 2000). Similarly, Acevedo-Garcia, Rosenfeld, McArdle, \& Osypuk (2010) noted complex and synergic nexuses between vulnerable children's social relationships at school, family, and the wider community.

However, this does not mean that there are no external realities informing or affecting vulnerable children's real-life schooling experiences. Social constructionism postulates that what is important in the study of vulnerable children is to understand how these children perceive and make sense of the world around them, and that it is the vulnerable children's socially and historically constituted relations that determine their real-life schooling experiences. While social constructionists are not in the business of dismissing reality, they do, however, question the objective existence of meaningful reality.

\begin{abstract}
Social constructionism doesn't try to rule on what is or is not fundamentally real. Whatever is, simply is. However, the moment we begin to articulate what there is-what is truly or objectively the case-we enter a world of discourse, and thus a tradition, a way of life and a set of value preferences. (Gergen, 2009, p. 161)
\end{abstract}

Rather than seeking facts and truths, this article was interested in the vulnerable children's social spaces and places-in the home and school-and how historically constituted repertoires of vulnerable children's relationships with these spaces informed constructions of these children's reallife schooling experiences. This theoretical perspective enabled the article to illuminate not only the spaces and places of vulnerable children's real-life schooling experiences but also the highly emotional value (due to often deeply held painful and traumatic memories, resulting from historically constituted social attachments and experiences some vulnerable children had in relation to these environments), which the vulnerable children attached to these spaces. Social constructionism draws on ideas of developmental psychology, influenced by the work of Lev Vygotsky (1978) and Jerome Bruner (Bruner \& Weinreich-Haste, 1987, p. 1), which has shifted in recent years from viewing children as active but isolated agents to an emphasis on children as active social beings: accepting that vulnerable children's "making sense [of real-life schooling experiences] is a social process; and an activity situated within [a] cultural and historical context." Indeed, vulnerable children's school experiences in this study were found to be inescapably immersed in discursively symbolised and regulated social relationships with close relatives, teachers, and other children within this context. When vulnerable children narrated stories about their real-life schooling experiences, we understood that these were not just vulnerable children's stories, but an embodied reflection of socially constituted relationships' dynamics in the 
communities, schools, and homes in which they lived. Sadly, the values preferences that teachers, relatives, and other children ascribed to vulnerable children, and vice versa, had the consequence of relegating the vulnerable children to subservience, often bearing the brunt of any thwarts emanating from these relationships.

\section{Real-life schooling experiences of vulnerable children}

Vulnerable children face challenges in community, family, and school contexts that bear devastatingly on their real-life schooling experiences. Communities tend to stigmatise and discriminate against them because they associate vulnerable children with social ills like poverty and HIV and AIDS (Nyabanyaba, 2009). Some communities, particularly in rural and poverty-stricken communities where almost everyone is struggling to meet basic means of subsistence, exhibit envy and jealousy towards vulnerable children who receive free aid-especially when this comes from rich international and Western organisations (Lekule, 2014). In family contexts, vulnerable children have real and important responsibilities in their lives that affect their study time (Mohlokwana, 2013). Some have lost both parents and live in child-headed households and, therefore, have to simultaneously address family responsibilities and meet schooling requirements (Nsibande, 2015). These complexities, and lack of proper and functional family structures, intensify the magnitude of vulnerable children's life challenges in ways that relegate them to inability to comply with their schooling requirements (Nelson \& Christensen, 2009)-like completion of assignments and arriving on time to school (Horgan, 2007). This then becomes a recipe for corporal punishment by teachers and, in some cases, expulsion from school (Nordtveit, 2010), whether constructively or directly by school principals who are normally keen to enforce the school rules and regulations.

Vulnerable children further face challenges of social exclusion as they try to fit into the school society (Vanderbeck \& Dunkley, 2004). For instance, other learners are terrified of playing with them due to an uninformed fear of contracting the HIV virus (Nyabanyaba, 2009). The negative constructions held about them and their menial social status render these children susceptible to bullying and ridicule by peers (Sukati, 2013). In addition, schools subject vulnerable children to unfair and unjust treatment (Sutton, et al., 2007), due to lack of understanding or appreciation of these children's life challenges and situations. Sometimes teachers and other children yell at the vulnerable children (Horgan, 2007) and intimidate them (Lekule, 2014), particularly because of the minority social status that they possess in the power hierarchies of social relationships within the schools. All these factors converge to compound the vulnerable children's situation in ways that exacerbate and add to their schooling plight and frustrations.

\section{Research Design}

\section{Research context}

The school in which this study was conducted is located in the rural Lubombo region on the far east of Swaziland, bordered by Mozambique. Lubombo is largely rural with $76 \%$ of its schools being in the rural areas (Kingdom of Swaziland, 2013). Due to the persistent drought, which has spanned more than 20 years now (Salam \& Mamba, 2012), the people of Lubombo have heavily relied on food aid because extreme poverty stands at $37 \%$ (Swaziland Central Statistical Office \& United Nations Children Fund, 2011), which makes it the poorest of the four regions in the country (UNICEF, 2009). Most people here live from piecework, and are paid in the form of food (Salam \& Mamba, 2012). Lubombo is also the area hardest hit by the effects of HIV and AIDS and, therefore, has the highest percentage of vulnerable children in the country (Braithwaite, Djima \& Pickmans, 2013). Furthermore, children in Lubombo are the most deprived of education (UNICEF, 2009), and are the most engaged in child labour (Nordtveit, 2010). 


\section{Research methodology}

A qualitative research paradigm was adopted as a methodological framing for the study. This paradigm was chosen for its ability to enable elicitation of quality active data, which explicates the complexities, dynamisms, and emotional subjectivities of socially constituted phenomena like real-life schooling experiences of vulnerable children (Cohen, Manion, \& Morrison, 2007). This allowed deeper access into the cultural contexts of the vulnerable children, and in an empowering manner that valued vulnerable children as active participants and coconstructors of knowledge about their real-life schooling experiences. Unlike a quantitative research paradigm, which uses numbers and instruments (Mcmillan \& Schumacher, 2010), qualitative research uses words, which privileges the vulnerable children's voices. In tandem with the theoretical perspective of this study, qualitative research is further concerned with the sociological nature of being and human experience (Mcmillan \& Schumacher, 2010). Its appreciation of complexities, contradictions, and fluidities of being, and the value of subjectivities in research, adds immense richness, liveliness, and dynamism to knowledge production. This approach allowed the researchers to describe and examine vulnerable children's individual and common societal actions, values, and perceptions (Bryman, 2008) regarding their lived schooling experiences within the immediate context in which these phenomena occurred (Mcmillan \& Schumacher, 2010). Through this approach, we were able to unearth complex, fluid, and supple realities that informed vulnerable children's understanding of the meanings, interpretations, and personal experiences of their schooling. We were further able to explore deeper into the social and personal world of the participants in more interactive, relational, and respectful ways. Moreover, the research participants had the opportunity to express their real-life schooling experiences from their own perspectives as children, using their own words.

\section{Data generation methods}

Individual and focus group semi-structured interviews and participatory photovoice techniques were utilised as methods of data collection. For photovoice, each participant was given a disposable camera with 27 frames. Pseudonyms, which the participants chose themselves, were used to name the cameras for ownership. The participants were trained on how to use the cameras, and were then urged to capture their chosen salient spaces and places that held meaning to their real-life schooling experiences either in an affirmative or undesirable way (Joubert, 2012) for a period of 4 days, after which the frames were developed. The photo imagery was then used during the interviews to act as ingress into the views, perspectives, and lived experiences of the study participants (Mitchell, Moletsane, Stuart, Buthelezi, \& de Lange, 2005). Photovoice enabled active involvement of the participants as they took the images and helped in their analysis. This asserted the participant children as active agentic actors not only in shaping dynamics of their lives, but also in shaping the knowledge they would like this study to produce in respect of their real-life schooling experiences.

\section{The study participants}

The study participants consisted of six Grade 6 vulnerable children (aged between 11-15 years). They consisted of three boys and three girls, who were purposively sampled. Two were orphans, two from child-headed households, and two from poverty-stricken families (one boy and one girl for each pair). As indicated earlier, orphaned children were those whose parents had died, and were left in the care of extended families. Children from child-headed households were either those whose parents had died, or were abandoned by their parents and lived in households where the eldest was less than 18 years old, or stayed with very old people whose livelihood depended on the vulnerable children. Participants from poverty-stricken families had both parents, but lived under very poor socioeconomic conditions. Regardless of the source of vulnerability, a common denominator that cut across these children was poverty, which relegated vulnerable children susceptible to the worst of social ills and challenges related to their schooling. 
With permission from the participants, the use of a tape recorder helped in the accurate capturing of what each participant said, and in supplementing data not recorded in notes. All interviews were conducted in SiSwati to allow participants to talk and express themselves without any linguistic restrictions (Mcmillan \& Schumacher, 2010).

\section{Data analysis procedures}

Data were transcribed from SiSwati into English for easy analysis. One of the authors is a Swazi, which thus helped with the analysis of transcriptions from SiSwati to English. An inductive process of analysis was followed to derive patterns and themes in the data (Braun \& Clarke, 2006). The emergent themes were then coded and the pictures selected and contextualised with assistance from the participants. Careful relistening to the recorded data was useful to ensure transcriptions' accuracy during generation of themes and with linking names of the actual informants to the pseudonyms used in this study. The participants' facial expressions and voice tone were noted in order to comprehend their emotions. The themes that emerged from all the data (photovoice, individual, and focus group interviews) were then analysed and discussed to derive the findings of this study.

\section{Ethical considerations}

Consent for the research was sought from the Director of Schools in Swaziland, the school principal, and from parents or caregivers of the participants. Considering that some vulnerable children had neither parents nor guardians, letters of consent for such participants were written to the umgcugcuteli [community caregiver]. Ethical clearance was obtained from the University of KwaZuluNatal research office. As the study views children as competent human beings who can decide on issues that concern their lives, their consent was also sought. In this paper, pseudonyms, which the participants chose themselves, are used to protect their identity.

\section{Findings}

\section{Vulnerable children's experiences in home and family spaces.}

Schooling experiences of every child does not begin when learners get into the school environment or end when the school day is over, but goes far beyond the school context to the community and home spaces (Nelson \& Christensen, 2009). For example, vulnerable children have to study and write assignments in their family spaces. Dynamics within the home settings were found to be contributing, somewhat negatively, to the real-life schooling experiences of the vulnerable children through the grief and trauma that these environments exposed them to. In addition, the absence of adult people (particularly their own parents) in their lives was also found to be devastating for these children, either emotionally or physically.

\section{Vulnerable children's trauma and grief}

The findings highlighted the traumatic experiences that the vulnerable children went through in their lives. There is evidence of huge emotional grief and distress that some vulnerable children underwent, and the stress these complications caused had likelihood to distract their concentration on learning. Picture 1, below, was provided by Anita to illustrate her daily distressing experience related to the suicide death of her father: 


\section{Picture 1}

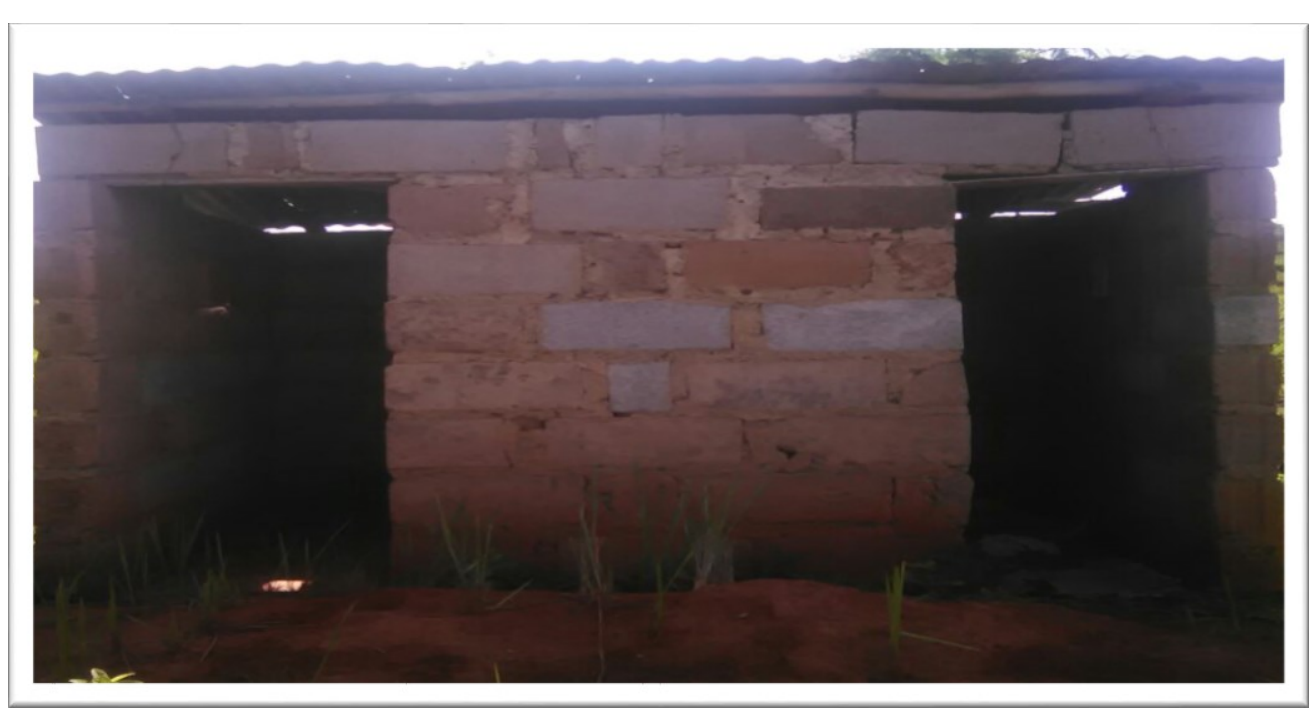

Anita (girl aged 12, focus group discussion): Lapha ngulapho babe atibulalela khona. Ngihlala njalo ngitibuta kutsi kwaba yini sizatfu sakhe. Kuyangilimata, noko ngiyati kutsi kute longanginika leto timphendvulo. [This is where my father committed suicide. I think about it almost every day. Why he really had to do this? It always hurt so much yet I know that I would never get the answers that I want].

The above excerpt demonstrates the pain and grief that some vulnerable children had to endure on a day-to-day basis. The emotional pain of seeing a place where her father committed suicide was a fact too hard to bear for a 12-year-old Anita. Unfortunately, there was no way in which this unsightly place could be removed from Anita's family compound, making it a place of horror to her on daily basis. There were no counselling services provided in this community, which means that Anita had to deal with all this on her own because her mother had also passed away. The plight of vulnerable children is really understated because the emotions they go through are usually not accommodated in many societal, community, and school structures, especially in the rural areas. The sight of a dead parent, or looking after a terminally ill parent who eventually dies in their care, was not uncommon among the six participants in this study. The findings indicate that the vulnerable children's real-life schooling experiences were emotionally laden, often due to deeply held painful and traumatic memories as a result of historically constituted social attachments and experiences they had in relation to these environments. Without properly organised assistance, therefore, children like Anita were not able to cope with schooling requirements (Nelson \& Christensen, 2009). Such emotional burdens that competed with their concentration on learning further aggravated their vulnerability. Furthermore, not being able to complete some school tasks and assignments predisposed the vulnerable children to punishment by teachers, which added to the level of their pain and discomfort.

The vulnerable children in the study were relegated to experience the bitter consequences of the breakdown of African and family values of communality because most of them were isolated and seen by extended family members as burdens due to a lack of financial resources to sustain their lives. This included the vulnerable children's educational requirements like school uniforms, and so forth. Separations from extended family members left some vulnerable children to shoulder the responsibilities of caring for themselves and their siblings emotionally and physically, as the excerpts below illustrate: 
Anita (girl aged 12, focus group discussion): Ngake ngacela malume kutsi angitsengele inyifomu yesikolwa, wangikhahlabeta matima. Wangitjela kutsi babe akabulawanga nguye. Njalo nangicabanga loku lakusho, ngitfukutsela kakhulu ngiyafisa kutsi babe ngabe usekhona. Lokuhlupheka nebuhlungu lobungaka ngabe angibhekani nabo [I once asked my uncle to buy me a school uniform and he was mean. He said he was not responsible for my father's death. I still think about the things he said and I have so much anger and I wish I had a father; he would have obviously protected me from this suffering].

Fortunate (girl aged 15, focus group discussion): Make wangishiya wayohlala eSkhwahlande. Umundeni wakhe awukhonanga kuhlala nami ngobe bakholelwa kutsi make ubalekela imisebenti yakhe njengemtali. Bebahlala njalo bangitjela kutsi make wehla uyenyuka lena eJozi. Nangisahlala nabo ngangihlala njalo ngikhala kani nalokutsi make vele wakhoh/wa kukhohlwa ngami, kuhlala njalo kungilimata kakhulu engcondvweni [My mother left me to stay in South Africa and her family refused to take care of me, because they felt she was running away from her responsibilities as a parent. They always told me that my mother was a very loose woman. I cried almost every day thus decided to go back home, and the fact that my mother completely forgot about me, affects me so much].

The data reveals the deep emotional scars, pain, and bitterness entrenched by both the circumstances that led to the vulnerable children's state of vulnerability, as well as by the denigrating manner in which their close relatives treated them as a result. The tendency by family members to reject vulnerable children had a devastating effect on these children's emotional, social, and psychological wellbeing, confirming social constructionism's argument that supportive social relations are important for vulnerable children to have positive constructions of their real-life schooling experiences. In particular, referring to the horrific incident of the death of Anita's father as a reason for not buying her a school uniform was the greatest form of emotional abuse. Anita was, clearly, deeply scarred by the experience of her father's suicide, which she witnessed just after it occurred-and daily afterwards in her school journey because she had to walk past the place where the suicide took place. The last thing she wanted in her life was to be reminded about this by a trusted uncle, who was supposed to be a source of joy and emotional comfort for Anita. Anita's uncle's remarks that he was not responsible for her father's death in justification of not buying Anita a school uniform had the likelihood to evoke a number of unpleasant emotions. First, to instil a notion that someone had to be blamed for the suicide death of Anita's father, which was futile given the context under which this was stated. Secondly, to make crystal clear the painful nexus between Anita's lack of school uniform and the death of her father-which merely served a dysfunctional purpose of relegating Anita to the brink of emotional breakdown. There is no doubt about the adverse implications of such an experience on Anita's ability to attend school and cope with the academic demands of schooling.

The lack of willingness by family members to assist vulnerable children is a deeply worrisome indication of African family disintegration, and a drift away from the spirit of African communalismcommonly known as Ubuntu, Buntfu in SiSwati. Historically, it took a village to bring up an African child, but with the status quo of unprecedented challenges of poverty, unemployment, and AIDS, the means of survival have become hard to come by. The findings indicated that these survival challenges had relegated most families in this Swazi community to conduct their lives along the "every person for herself or himself and God for us all" principle. Sadly, this mentality brings no good news for the vulnerable children who, to the very contrary, desperately require more support, care, and belonging from their families and communities than at any time before (Wood \& Goba, 2011), owing to the challenges of abject poverty, unemployment, and the scourge of AIDS. 


\section{Absence of adult or parents in vulnerable children's lives}

The study findings showed that the absence of adult people in home contexts brought about negative experiences, with consequent responsibilities that competed with the vulnerable children's study time-lack of necessities, chaotic home environments, and relatives who took advantage of the vulnerable children, as illustrated below:

Anita (girl aged 12, individual interview): Khokho kute nakunye lakwentako. Mine ke kudzingeka ngimunakekele, ngipheke, ngiwashe, ngiphindze ngiciniseke kutsi ngakusasa kukhona latokudla mangisesikolweni. Uma sekudzingeka ngidadishe, emva kwawowonkhe lomusebenti lona, ngisuke sengidzinwe kakhulu kutsi ngingenta lutho [My great-grand mother literally does nothing and I have to do all the work, take care of her, cook, wash and also make sure that when I go to school the next day, she has something to eat. By the time I have to study, I am just too tired to do anything].

Precious (girl aged 13, focus group discussion): Uma ngibuya esikolweni onkhe malanga, ngiyacabanga ngelilanga lelilandzelako ngoba ngati kutsi lemisebenti lengidzinga kutsi ngiyente ekhaya, kupheka nalokunye lokunenti, itongenta ngingatfoli litfuba lekwenta umsebenti wami wesikolwa. Ngako ke ngiyati kutsi luswati vele lungihlalele. Ngesikhatsi sengicedzile ngisuke sengidziniwe, ngingacabangi ngsiho kucabanga ngemusebenti wesikolwa. Ngalesinye sikhatsi sekuhwalele, ukhandze kutsi nelikhandlela kute [When I get home from school every day, I worry about the next school day because I do not get enough time to do my schoolwork and, obviously, the teachers will punish me. I usually have too much work to do, like cooking for the family and other house chores. By the time I am done, I am usually so tired that I do not even think of my schoolwork or we do not have a candle for lighting].

Below, Picture 2, is pictorial evidence of one of the chaotic environments the vulnerable children were subjected to in the home context:

\section{Picture 2}

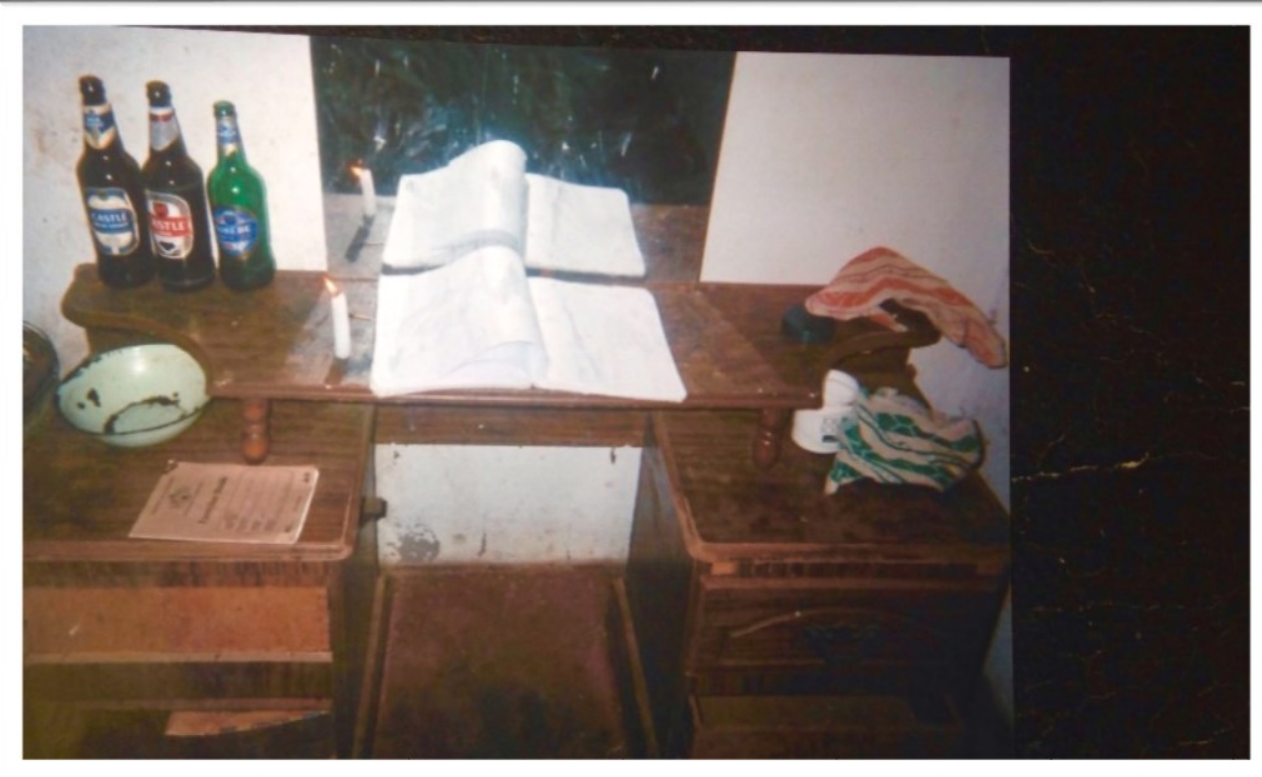


Gustuff (boy aged 13, individual interview): Lesitfombe sikhombisa ingcinamba njelengibhekana nayo imihla nemalanga. Esimeni lesinjena angikhoni kunaka umsebenti wami wesikolwa. Mzala wahlala angitfuma ngiyomutsengela tjwala neligwayi ngisho lilanga selishonile, akangenelani nekutsi mine loko kungiphatsa njani. Kute ke lengingakwenta ngaphandle kwekutsi ngente lakushoko ngoba sondliwa nguye. Eskhatsini lesinengi usuke adzakiwe, abange umsindvo nge radio, amemete-nawo longikhubako phindze ungiphatamise uma ngifuna kubhala umsebenti wesikolo noma ngidadishe [This picture shows what I have to deal with on daily basis. In such a set-up, concentrating on my homework is impossible. My cousin always sends me to buy him alcohol or cigarettes even during the late hours and he does not care how that makes me feel. I have no alternative but to comply because he is the one who buys food. Most of the time he is drunk and the loud music and noise that he makes also frustrates me when I want to study or write homework].

From the narratives above, it is apparent that the vulnerable children's real-life experiences were informed by historically constituted unequal power relationships between children and adults (Gergen \& Gergen, 2000), which led to Gustuff's cousin's exploitative abuse of his guardianship authority. We determined that vulnerable children, like Anita in this context, were forced by circumstances to grow up into adults by doing chores and taking over responsibilities that were way beyond their ages, whilst other children of the same age enjoy being children (Evans \& Pilyoung, 2013). Gustuff seemed to be profusely contradicted in his identities as a schoolchild and cigarette and alcohol delivery boy, coupled with late night music when he still had to wake up early and be attentive in the classrooms the following day. Evidently, such chaos at a family level did not contribute positively to the real-life schooling experiences of vulnerable children like Gustuff who had to navigate complex and contradictory demands of having to do his homework in the midst of alcohol and loud music late at night.

From these findings, it is clear that in poverty-stricken households, family members who are generally not the biological parents of the vulnerable children, tended to be less responsible. The evidence points to these members' propensity to misuse or overuse the dominant African adult-child relationship where the assumption is that elders have many issues to deal with emotionally and physically pertaining to the welfare of the home, justifying delegation of all the mundane family chores to the vulnerable children. Such an approach characterised many a Swazi family (Nelson \& Christensen, 2009), even in cases where there were no issues of vulnerability. Non-vulnerable children are unfavourably affected by this practice-and even more severely so by vulnerable children. Exploiting vulnerable children to perform any form of extra labour that does not support their developmental rights as children (like education) is flawed with negative and unjust implications, and cannot be justified by any cultural and moral principle. This shows the centrality of compassionate, sensitive, respectful, and nonexploitative social relations as basis for the enhancement of vulnerable children's real-life schooling experiences.

\section{Vulnerable children's experiences in school spaces}

As stated earlier, social constructionism posits that the social relations that vulnerable children have with their teachers regulate how they construct their real-life schooling experiences (Gergen \& Gergen, 2000). Indeed, the findings indicated the central role that teachers' relationships and interactions with the vulnerable children played to inform these children's real-life schooling experiences. Teachers' and vulnerable children's relations could be understood as both productive and unfavourable. 


\title{
Caring teachers
}

The study found a prevalence of good and affirmative relationships between some teachers and vulnerable children in this school. These teachers were found to be compassionate and responsive to the plight of the vulnerable children. There was evidence of care and concern for their well-being and welfare as illustrated below:

\begin{abstract}
Precious (girl aged 13, focus group discussion): Linengi lebantfwana lapha esikolweni bayagula, umphatsi uyaya ayobahlola emakhaya uma bangasakhoni kuta esikolweni. Lokunye, uyacinisekisa kutsi ngaso sonkhe sikhatsi lapha esikolweni kukhona lesingakudla ngoba uyati kutsi linengi letfu ngeke sikhone kuphila ngaphandle kwalokudla lesikutfola lapha esikolweni [We have many sick children in the school and the principal checks on their health when and if they get sick and can no longer come to school. In addition, he ensures that we always have something to eat because he is aware that most of us cannot survive without the food provided by the school].
\end{abstract}

Ayanda (boy aged 11, focus group discussion): Ebusika, labanye bothishela basitsengela ticatfulo nemajezi. Siyabonga kutsi basicabangele nome nabo banetinkinga tabo [During the winter season, the teachers usually buy school shoes and jerseys for us. We appreciate the little that they do for us under their own circumstances].

Fortunate (girl aged 15, individual interview): Uma kukhona longakuva uma kufundvwa, ungaya kulomunye thishela uyobutisisa. Siya kubothishela labasiphatsa kahle. Labanye bothishela beva ngatsi singumutfwalo [If you have not understood a concept in class, you can go to another teacher for clarity. Usually we go to the teachers that are good to us, because other teachers feel we are a burden and like attention].

Showing compassion and care towards vulnerable children was the kindest gesture of moral benevolence demonstrated by the principal and some teachers in this school. The positive ramifications that caring teachers brought to the vulnerable children not only reverberate in the tones of the children's narrations of these stories, but are indeed impactful on the quality of these children's real-life schooling experiences. The data confirms that vulnerable children felt welcome and content (Lupton, 2004) in schools where teachers were caring, loving, and took interest on their lives, making love and compassion an essential obligation for effective learning of vulnerable children. When there are no parents to care for the vulnerable children, and their extended families are neglecting and abusing them, it seems that the school was a place of hope for the vulnerable children in this study. Some teachers have begun to take responsibility on their own shoulders to alleviate the plight of the vulnerable children. This may mark the beginning of a turnaround in Swazi schools in respect of teachers' willingness to expand their roles beyond mere classroom pedagogical didactics to using their influential professional positions to play broader grief alleviation, social support, and transformational roles.

It should be noted however, that such extended show of support by teachers could be very emotionally draining for the teachers (Wood \& Goba, 2011). Support mechanisms are therefore necessary to help caring teachers to become of maximum benefit to vulnerable children, without also comprising their own well-being. Among others, such support may come in the form of equipping teachers with skills on how to work with, care for, and teach vulnerable children effectively.

\section{Uncaring teachers}

The findings also revealed negative ways in which vulnerable children constructed their real-life schooling experiences in the school, particularly in cases where teachers subjected the vulnerable 
children to unfair treatment and marginalisation. These learners claimed that teachers chastised them for offenses that were beyond their control and used different ways to mete out punishment. Hence, punishment by teachers came out very strongly amongst all the respondents of the study. They felt it was unfairly skewed against them as vulnerable children, which is evident from the narratives below:

Sifiso (boy aged 12, individual interview): Lendlela lebasishaya ngayo inesihlungu lesimatima, emvakwekushaywa vele singabe sisakhona kufundza kahle. Phandle kwaloko nje, bothishela bayakhetsa, basijezisa ngendlela lengafani neyalabanye bafundzi-ngobe tsine sihluphekile [The punishment is just too much for us to bear and we cannot really concentrate after the beating. Besides, the teachers are choosy when it comes to the punishment; teachers punish us differently from other learners because we are poor].

Gustuff (boy aged 13, focus group discussion): Mmmmmm lendlela lesishaywa ngayo isenta singasitsandzi sikolwa. Bothishela bavele bakubuke emehlweni; uma utiphuyele bakushayisa kwentfo lenganamusebbenti. Bafundzi labaphuma emakhaya lakeme kahle noma bangenti kahle, bona bayacolelwa melula [Mmmmmmm - the punishment makes us hate school [The tendency for children to speak in plural terms, not only for themselves was prevalent in this study, more as a cultural expression of communality linked to the African principles of ubuntu rooted in the Swazi local language dialect). The teachers just look at you in the eye; if you are poor, they punish you like a useless thing. If learners from better off families misbehave, they are easily forgiven].

Fortunate (girl aged 15, focus group interview): Uma kwentekile wefika esikolweni muva noma ngemizuzu lesihlanu, ushaywa nge duster etingalweni noma kutsiwe hamba uyosebenta engadzeni labanye bafundzi babe bachubeka nekufundza. Bayasitsetsisa, lomunye thishela wake wangitjela kutsi ngibahambela ngcunu ngekutsi nje ngangigcoke inyifomu ledzabukile. Bothishela abatihluphi ngekutfola kutsi sentiwa yini kufika muva esikolweni. Bavele basitjele kutsi si bantfwababogogo. Ngalesinye sikhatsi basitjele kutsi sibadzala kunaleli class lesikulo [If you come late to school, even 5 minutes late, you are punished by being beaten with a blackboard duster on the head or you work in the garden whilst the other learners continue with classes. They rebuke us; a teacher once told me I was naked because I was wearing a torn uniform. Teachers do not even bother to find out why we are usually late. They say we are spoiled brats. At times, they tell us that we are too old for that class].

The photograph, Picture 3 below, was provided by Gustuff to illustrate the way teachers punished vulnerable children in the school.

\section{Picture 3}

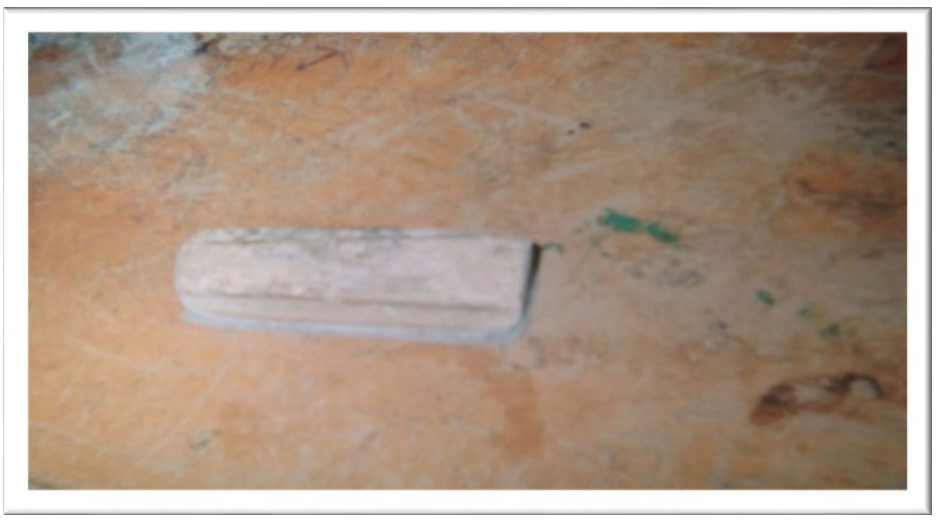


Gustuff (boy aged 13, focus group discussion): Lesitfombe sitjengisa I blackboard duster bothishela labasishaya ngayo noma sente emaphutsa lamancane kakhulu. Abakhulumi natsi kuva tinkinga lesinato letisenta singenti kahle-bavele basikhahlabete [This picture shows a blackboard duster used by teachers to punish us for very petty offenses. They do not talk to us, to find out about the challenges that we have-all they do is shout at us].

The findings indicate how the use of corporal punishment as a behaviour corrective mechanism is inequitably antagonistic towards vulnerable children. The social circumstances of lack of support, neglect, and abuse by extended family members naturally predisposed the vulnerable children's inability to comply with some rigid school regimes. For example, arriving on time in school, wearing proper school uniform (one that is not torn, least the child is labelled as coming naked to school, as the 15-year-old girl, Fortunate, has stated above), completing assignments, and so forth. Therefore, the likelihood that vulnerable children would feature in cases requiring corporal corrective punishment is very high; perhaps this might account for the feeling from the vulnerable children that teachers seemed to be targeting them as opposed to children from rich or conventional families. It is also logical to assume that children from rich or conventional families may have all the necessary support structures, which makes it easy for them to comply with and meet most of the school requirements.

Corporal punishment was propagated as a dominant sociocultural children's behaviour modification practice in Swaziland (Nordtveit, 2010), often justified on grounds of the age-old biblical scriptures of "spare the rod, spoil a child" logic. Yet findings indicate that the rod must be spared, not with intent to spoil the child but recognising the social backgrounds of children as being the root cause of their ill behaviour. Although corporal punishment informed real-life schooling experiences of the vulnerable children, there was no evidence that this practice achieved its intended outcomes-raising question as to the effectiveness of this form of punishment, in general, as a behaviour modification strategy. Certainly, corporal punishment has huge potential to change children's behaviour, but sadly not in line with the teachers' expectations. As the 13-year-old boy, Gustuff, furiously lamented, "Mmmmmmmm - the punishment makes us hate school." Actually, instead of coercing learners to do what teachers expect, corporal punishment does the opposite-it chases children away from school (Nordtveit, 2010), and made the vulnerable learners hate school and the teachers. All of this worked against the best interests of both the teachers, vulnerable children, and the broader Swazi national agenda of using education as a tool for social, economic, and human development (Sutton, et al., 2007). For these children, administering corporal punishment was a huge gesture of lack of love and care that teachers demonstrated and which had a compounding rather than mitigating effect on the severity of vulnerable children's real-life schooling experiences.

These findings add to wider regional and international calls for the abolishment of corporal punishment as a means of reprimanding children in schools. Actually, neighbouring South Africa has long passed a law that abolishes corporal punishment, and teachers who practise this commit an offense that is punishable by law. Perhaps it is time for Swaziland to join in these developmental strides, which are all aimed at cherishing, supporting, and respecting all learners as competent members of society who deserve humane and considerate treatment just like any human members of our societies.

\section{Discussion, Conclusion, and Recommendations}

Socially constructed relationships were not only the means by which vulnerable children constructed their real-life schooling experiences (Gergen, 2009). In the bigger scheme of things, vulnerable children themselves, were a product of thwarted socially constituted historical relationships. Almost all life incidents that relegated children to vulnerability, and the vulnerable children's real-life schooling experiences, were deeply suffused in complex social relationships or lack thereof. For instance, the 
brutal death of a parent, abuse by close relatives or schoolteachers, dysfunctional families, teacher relationships at school, and so forth. The real-life schooling experiences of vulnerable children were suffused with fleeting moments of love and care, and enduring moments of grief and trauma. The moments of grief and trauma were mainly indicated by the painful incidents like the loss of a parent (which usually led to, or exacerbated, children's degree of vulnerability) and the manner in which teachers and relatives treated the vulnerable children as well as neglect and abuse by extended family members. The moments of love and care mainly came from the vulnerable children's school-based social relations and experiences, albeit these were a combination of love, care, and support from some teachers, mixed with exclusion and verbal abuse from other teachers. Notable among the unpleasant experiences at the school level was teachers' administering of corporal punishment as a behaviour corrective mechanism. This was found to not only be a form of unjustifiable physical abuse, but also inequitably militating against the vulnerable children. Such a strategy left vulnerable children with no recourse but to hate school-which may account for the high incidence of primary school drop out in Swaziland (Nordtveit, 2010). An aggravating factor to the challenge of school drop out was the apparent lack of opportunities for vulnerable children to organise their lives in other spaces because the school-home interfaces were the main, if not the only, social spaces and places that informed these children's real-life schooling experiences in this rural context. This left the vulnerable children with little or no buffer zones to mitigate the effects of their unfavourable experiences.

The following recommendations are made as possible ways through which the quality of vulnerable children's real-life schooling experiences can be enhanced:

- Teachers' administering of corporal punishment in Swazi schools should be made illegal and punishable by law.

- In-service teacher workshops and seminars meant to deconstruct the negative stereotypes and stigmas associated with poverty and HIV and AIDS should be convened. This is because most vulnerable children in this context were either directly or indirectly associated with these social ills. Therefore, the dominant discourse closely associated with vulnerable children, in light of the misconceptions related to these social challenges, needs to be deconstructed.

- Reskilling of teachers with the appropriate teaching and social skills for dealing with vulnerable children is equally important. This is because teachers' lack of expertise regarding the facts and social realities of vulnerable children was found to play a major role in unfair and insensitive responses teachers made towards the transgressions committed by the vulnerable children. As stated above, most of the offenses committed by vulnerable children were due to circumstances beyond their control.

- Inception of social justice, diversity, and inclusive education modules should be made compulsory in all preservice teacher training institutions in Swaziland.

The above recommendations would be futile without foregrounding social relationship enhancement as an underpinning, overarching strategy to address the question of childhood vulnerability and unfavourable schooling experiences of vulnerable children in this context.

\section{References}

Acevedo-Garcia, D., Rosenfeld, E. L., McArdle, N., \& Osypuk, T. S. (2010). The geography of opportunity: A framework of child development. In C. Edley \& J. Ruiz de Velasco (Eds.), Changing 
places: How communities will improve the health of boys of colour (pp. 358-406). California, USA: University of California Press.

Braithwaite, J., Djima, L., \& Pickmans, R. (2013). Child and orphan poverty in Swaziland. Virginia, USA: UNICEF.

Braun, V., \& Clarke, V. (2006). Using thematic analysis in psychology. Qualitative Research in Psychology, 3(2), 77-101.

Bruner, J. S., \& Weinreich-Haste, H. (1987). Making sense: The child's construction of the world. London, UK: Methuen.

Bryman, A. (2008). Social research methods (3rd ed.). New York, USA: Oxford.

Cohen, L., Manion, L., \& Morrison, K. (2007). Research methods in education (6th ed.). New York, USA: Routledge Falmer.

Evans, G. W., \& Pilyoung, K. (2013). Childhood poverty, chronic stress, and self-coping. Child Development Perspectives, 7(1), 43-48.

Gee, J. P. (2011). An introduction to discourse analysis: Theory and methods (3rd ed.). New York, USA: Routledge.

Gergen, K. J. (2009). An invitation to social constructionism. London, UK: SAGE.

Gergen, M. M., \& Gergen, K, J. (2000). Qualitative inquiry: Tensions and transformations. In N. K. Denzin \& Y. S. Lincoln (Eds.), Handbook of qualitative research (pp. 1025-1046). London, UK: SAGE.

Horgan, G. (2007). The impact of poverty on young children's experiences of school. New York, USA: Joseph Downtree Foundation.

Joubert, I. (2012). Children as photographers: Life experiences and the right to be listened to. South African Journal of Education, 32(4), 449-464.

Khumalo, T. (2013). Swaziland: Effective delivery of public services. Pretoria, South Africa: Open Society Initiative for Southern Africa.

Kingdom of Swaziland. (2005). The Constitution of the Kingdom of Swaziland in English and SiSwati. Retrieved from http://www.wipo.int/edocs/lexdocs/laws/en/sz/sz010en.pdf

Kingdom of Swaziland. (2010). National plan of action for children (NPA) 2011-15. Retrieved from http://washinschoolsmapping.com/wengine/wp-content/uploads/2015/10/Swaziland-NationalPlan-of-Action-for-Children.pdf

Kingdom of Swaziland. (2011). The Swaziland education and training sector policy. Retrieved from http://planipolis.iiep.unesco.org/upload/Swaziland/SwazilandEducationSectorPolicy2011.pdf

Kingdom of Swaziland. (2012). Swaziland Government Gazette, no 12 (Vol XLX). Mbabane, Swaziland: Government Printer.

Kingdom of Swaziland. (2013). Swaziland schools' lists, 2013 [Ministry of Education \& Training circular]. Mbabane, Swaziland: Government Printer.

Lekule, S. (2014). Investigating school experiences of vulnerable children in Singida, Tanzania: Challenges, strategies, and possible intervention (Doctoral dissertation, University of Windsor, Canada). Retrieved from http://scholar.uwindsor.ca/cgi/viewcontent.cgi?article=6081\&context=etd

Lupton, R. (2004). Schools in disadvantaged areas: Recognising context and raising quality. Retrieved from https://core.ac.uk/download/pdf/7119297.pdf

McCann, C. R., \& Kim, S. (2003). Feminist theory reader. New York, USA: Routledge. 
Mcmillan, J. H., \& Schumacher, S. (2010). Research in education. Evidence-based inquiry (7th ed.). New Jersey, USA: Pearson.

Mitchell, C., Moletsane, R., Stuart, J., Buthelezi, T., \& de Lange, N. (2005). Taking pictures/ taking action! Visual methodologies in working with young people. Children First, 9(60), 27-30.

Mohlokwana, M. A. U. (2013). Care and support for vulnerable children in schools: The case of childheaded families. Journal of Social Science, 36(1), 11-13.

Nelson, E., \& Christensen, K. (2009). Photo-voice in the middle: How our students experience learning at school and beyond. New Zealand Journal of Teachers' Work, 6(1), 35-46.

Nordtveit, B. (2010). Schools as agencies of protection in Namibia and Swaziland: Can they prevent dropout and child labour in the contexts of HIV/AIDS and poverty? Comparative Education Review, 54(2), 223-242.

Nsibande, B. (2015, March 15). Fifteen-year-old boy sleeps under hospital bed. Times of Swaziland, p. 4.

Nyabanyaba, T. (2009). Factors influencing access and retention in secondary schooling for orphaned and vulnerable children, and young people: Case studies from high HIV and AIDS prevalence contexts in Lesotho. London, UK: SOFIE.

Salam, A., \& Mamba, E. (2012). Approaches used by government and non-governmental organisations (NGOs) in promoting crop production and its implication on food security and hunger in Swaziland: A case study of Sithobela area. Journal of Sustainable Development in Africa, 14(3), 57-71.

Simelane, M. (2016, January 28). OVC crisis as applicants double. The Times of Swaziland, p. 1.

Sukati, C. W . S. (2013). Education for all children by 2015: Mere rhetoric or reality in Swaziland? International Journal of Education and Research, 1(11), 1-12.

Sutton, L., Smith, N., Dearden, C., \& Middleton, S. (2007). Child's eye view of social difference. New York, USA: Joseph Rowntree Foundation.

Swaziland Action Group Against Abuse (SWAGAA). (2013). Effectiveness of a comprehensive sexual and gender-based violence prevention project for in-school girls in Swaziland. Manzini, Swaziland: SWAGAA.

Swaziland Central Statistical Office \& United Nations Children Fund. (2011). Swaziland multiple indicator cluster survey 2010. Mbabane, Swaziland: Central Statistical Office.

UNESCO. (2000). The Dakar framework for action 2000. Retrieved from http://www.unesco.org/carneid/dakar.pdf

UNICEF. (2009). Promoting quality education for orphans and vulnerable children. A source book of programme experiences in Eastern and Southern Africa. Retrieved from http://www.unicef.org/spanish/education/files/Promoting Quality Education for Orphans and Vulnerable Children Programmes from Eastern and Southern Africa.pdf

Vanderbeck, R., \& Dunkley, C. (2004). Introduction: Geographies of exclusion, inclusion and belonging in young lives. Children Geographies, 2(2), 177-183.

Vygotsky, L. (1978). Interaction between learning and development. Readings on the Development of Children, 23(3), 34-41.

Wood, L., \& Goba, L. (2011). Care and support for orphaned and vulnerable children at school: Helping teachers to respond. South African Journal of Education, 31(2), 275-290. 